\title{
Intervention of Students With Specific Needs At The University of St. Cyril And Methodius In Trnava
}

\author{
Ol'ga Bočáková1, Michal Imrovič ${ }^{2}$ Darina Kubíčkováa ${ }^{3}$, Andrej Martoš ${ }^{4}$
}

\begin{abstract}
In the paper we focus on the target group - students with specific needs. These are students with disabilities. We describe individual disabilities, the creation of a Support Centre for Students with Special Needs. We focus on its activity, mission. We describe what support services are provided to students with specific needs. The need for support services for students with special needs is mapped by faculty coordinators, who work closely with the university coordinator. What support services are provided to students with special needs is regulated by legislation, the Higher Education Act. We present the number of students with special needs for the last five years: from 2016/2017 to 2020/2021. In this paper we present a picture of good practice focused on the intervention of students with special needs at the University of St. Cyril and Methodius in Trnava with emphasis on the Faculty of Social Sciences University of St. Cyril and Methodius in Trnava. What is the intervention we obtain on the basis of interviews with the Vice-Rector for Education, the head of the Support Centre for Students with Special Needs and the selected students with special needs of the Faculty of Social Sciences University of St. Cyril and Methodius in Trnava. Our findings from the testimonies of participants, students with specific needs we will then be implemented in practice.
\end{abstract}

\section{Keywords}

studenats, specific needs, disability, coordinator, support centre, intervention, support services, university

\section{Introduction}

People with disabilities also have the right to education. Persons with disabilities have their support in the un convention on the rights of persons with disabilities, which enshrines the right of persons with disabilities to education without discrimination, on the basis of equal opportunities, in order to ensure an inclusive education system at all levels. [2]

The purpose of the text is to present the center for support of students with special needs at the university of st. Cyril and methodius in trnava with emphasis on the faculty of social sciences ucm in trnava, to emphasize its importance for students with special needs.

The aim of the paper is to approach the target group - students of the university of st. Cyril and methodius in trnava with specific needs. Point out the possibilities of their intervention, inclusion in society. The aim is to highlight the importance of intervention for people with disabilities and people with special needs.

\section{Support Centre for students with special needs}

The aim of creating conditions to support students with special needs at universities is to create an institutional document. This document - Methodological Guideline expresses the policy of higher

1 University of St. Cyril and Methodius in Trnava, Faculty of Social Sciences, Trnava (SLOVAK REPUBLIC), olga.bocakova@ucm.sk 2 University of St. Cyril and Methodius in Trnava, Faculty of Social Sciences, Trnava (SLOVAK REPUBLIC), michal.imrovic@ucm.sk 3 University of St. Cyril and Methodius in Trnava, Faculty of Social Sciences, Trnava (SLOVAK REPUBLIC) 4 University of St. Cyril and Methodius in Trnava, Faculty of Social Sciences, Trnava (SLOVAK REPUBLIC) 
education towards creating a generally accessible academic environment. It is a debarierization of archectonic but also information with emphasis on the implementation of advanced information and communication technologies and services. [11]

The Council of the Minister of Education, Science, Research and Sport of the Slovak Republic to support the study of students with special needs stated that several universities do not have adopted directives, internal regulations that would specify the creation of university support centres to support the study of students with special needs. The Council of the Ministry of Education, Youth and Sports of the Slovak Republic proposed the certification of support centres managed by the Council, the condition for financing the university support centre is obtaining a certificate. Obtaining the certificate is a condition for financing the university support centre from the specified specialpurpose subsidy. [4]

A student with special needs is a university student with a disability. Within the university, the coordinator of the entire university works, if there is a support centre, then it is the head of the centre. The faculty coordinator of the university works within the relevant faculty.

\section{Students with special needs - characteristics}

The individual categories are characterized by Section 100 of the University Act as follows:

\section{Students with sensory, physical and multiple disabilities}

They belong here:

- blind students,

- visually impaired students,

- deaf students,

- hard of hearing students,

- students with lower limb disabilities,

- students with upper limb disabilities,

- students with multiple disabilities - multiple types of disabilities.

\section{Students with chronic diseases}

It is about:

- cystic fibrosis,

- epilepsy,

- multiple sclerosis,

- cardiovascular disease,

- neurological diseases,

- after organ or tissue transplantation,

- and other.

\section{Students with impaired health}

It is a long-term sick student with subsequent convalescence, reduced resistance to disease. Also about a student with a health risk due to an unsuitable environment, improper nutrition, improper lifestyle.

\section{Students with mental illness}

The student has mental difficulties, his current mental state, mental health disorder affects the ability to fulfil study obligations in the standard mode.

Students with autism or other pervasive developmental disorders (severe mental development disorders in childhood):

This includes, for example, Asp erg's syndrome, which is characterized by disruption of social relationships. It affects the ability to fulfil study obligations in the standard mode.

\section{Students with learning disabilities}

There are significant difficulties in reading, writing, counting, listening and communicating. It can be:

- dyslexia - difficulty reading and writing

- dysorthography - problems in written expression, various mistakes, inability to express oneself grammatically

- dysgraphia - a writing disorder that manifests itself in different font shape, different height, 
inclination, etc.

- dyscalculia - disorder of mathematical actions [11]

\subsection{Centre for support of students with special needs at the University of St. Cyril and Methodius in Trnava}

The Centre for Support of Students with Special Needs was established in 2012 and its goal is to help and support students of all parts of UCM in Trnava in the following areas:

- psychological counselling

- Social counselling

- support for students with special needs with sensory, physical and multiple disabilities

- support for students with chronic illnesses, mental illnesses, people with disabilities, autism,

learning disabilities

A Guideline has been developed to ensure a generally accessible academic environment for students with special needs. The centre is governed by the Decree of the Ministry of Education, Youth and Sports of the Slovak Republic no. 458 of 2012 on the minimum requirements for a student with special needs. [10]

The mission of the Centre is organizational, coordination, educational and methodological activities, which are focused on creating an accessible academic environment and creating appropriate conditions for students with specific needs. The support centre for students with special needs at UCM in Trnava provides the following activities:

- registration of applicants and registration of students with special needs

- awareness of study conditions by applicants with specific needs

- coordinates services and assistance to students (study assistance)

- counselling and solving individual study issues of students with specific needs

- cooperates with teachers with specific needs at individual faculties

- ensures and coordinates projects related to the support of students with special needs and other [7]

We provide an overview of the number of students with special needs from 2016/2017 to 2020/2021.

\section{Graph 1 Development of the number of students with special needs from 2016/2017 to 2020/2021}

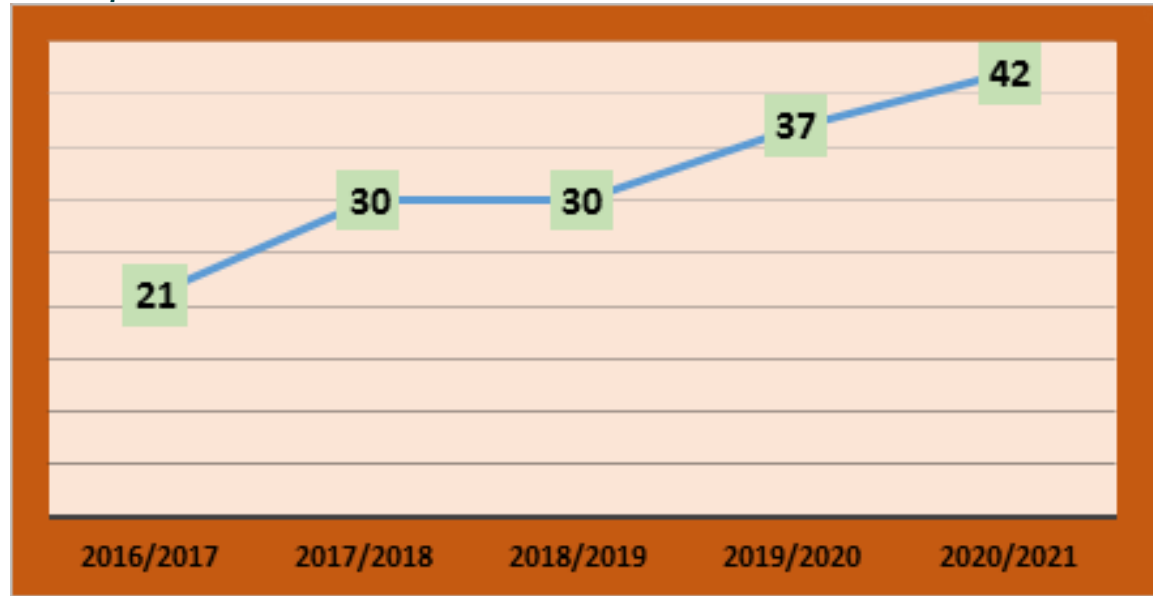

Source: Own processing based on the Evaluation Report of the Centre for Support of Students with Special Needs [3]

It is clear that the number of students with special needs is growing. The following graphs show the number of students with specific needs by disability in 2018/2019, 2019/2020 and 2020/2021. 


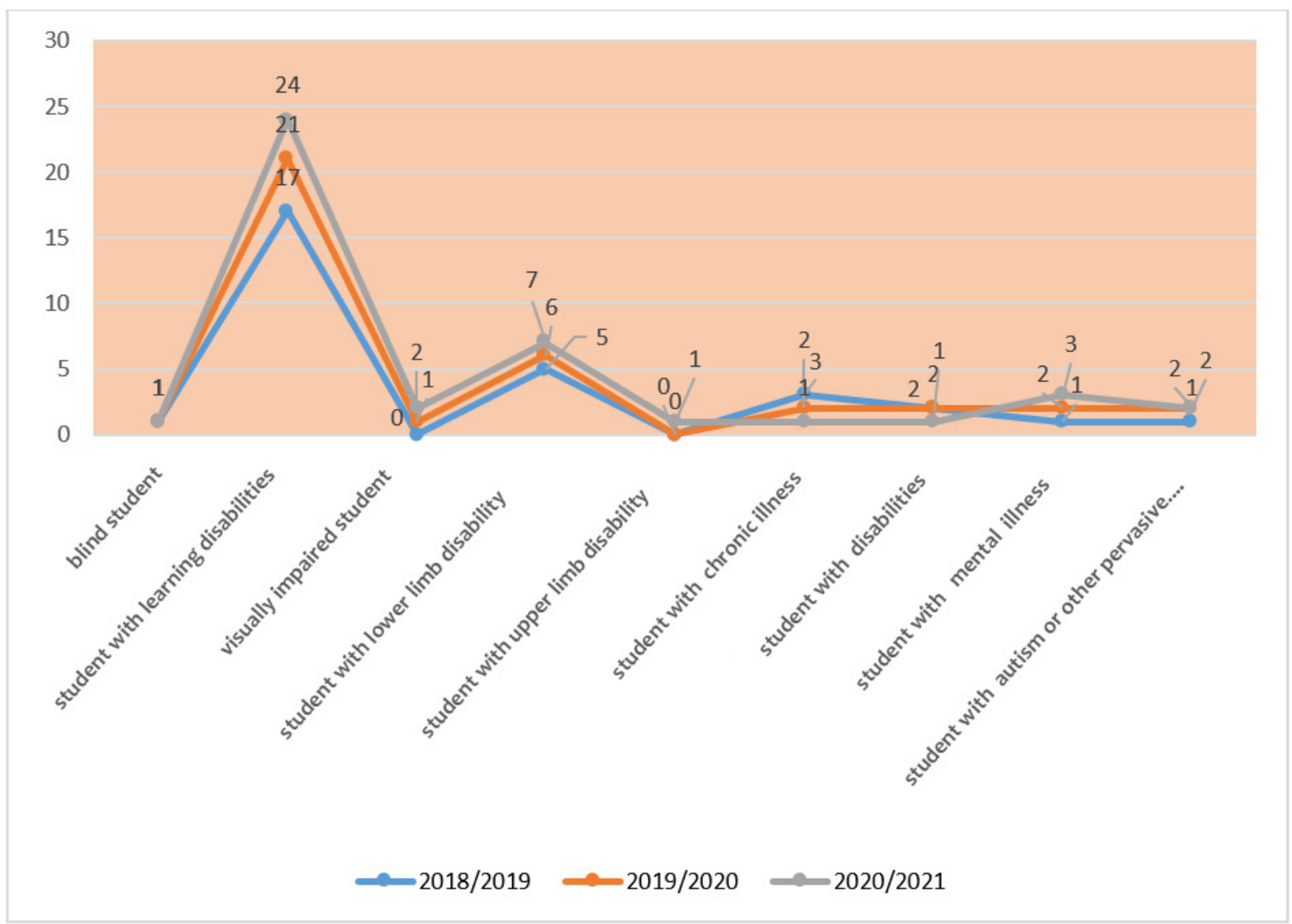

Source: Own processing based on the Evaluation Report of the Centre for Support of Students with Special Needs [3]

We can see from the graph that most students have a learning disability in all academic years. This is followed by students with physical disabilities of the lower limbs. University of St. Since 2015, Cyril and Methodius in Trnava has been using funds for students with special needs allocated from a special-purpose subsidy provided by the Ministry of Education, Youth and Sports of the Slovak Republic. Funds are provided according to the type of specific needs registered at the UCM in Trnava as of the 31.10. of the relevant year.

\subsubsection{Intervention of students with special needs in the context of support services at the University of St. Cyril and Methodius in Trnava}

UCM in Trnava provides support services to students with special needs. The student must apply for support services, then his requirements will be examined to see if they are in line with his needs. The basis for the provision of support services are medical certificates and statements of experts, whether psychologist, speech therapist, special pedagogue. Forms of support services are:

- modified conditions for entrance exams

- use of specific educational resources

- individual educational approach (individual study plan)

- determination of special conditions for the performance of study obligations

- individual approach of the university teacher

- forgiveness of tuition fees

- remission of the fee for exceeding the standard length of study due to the specific need of the student

- on the proposal of the Vice-Rector, the administration of accommodation and catering facilities for students with special needs will ensure accommodation and meals within the possibility so that the premises correspond as much as possible to accessibility, accessibility

Location of aids for students with special needs:

- Computer workstations are set aside in the study room of the UCM University Library 
- The entrance to the UCM University Library building is equipped with a bell for immobile students

- The entrance to the building is secured by a platform for barrier-free access

- Parking spaces for students with disabilities are reserved at individual UCM buildings

- and others [9]

\section{Figure 1 Selected aids for students with special needs}

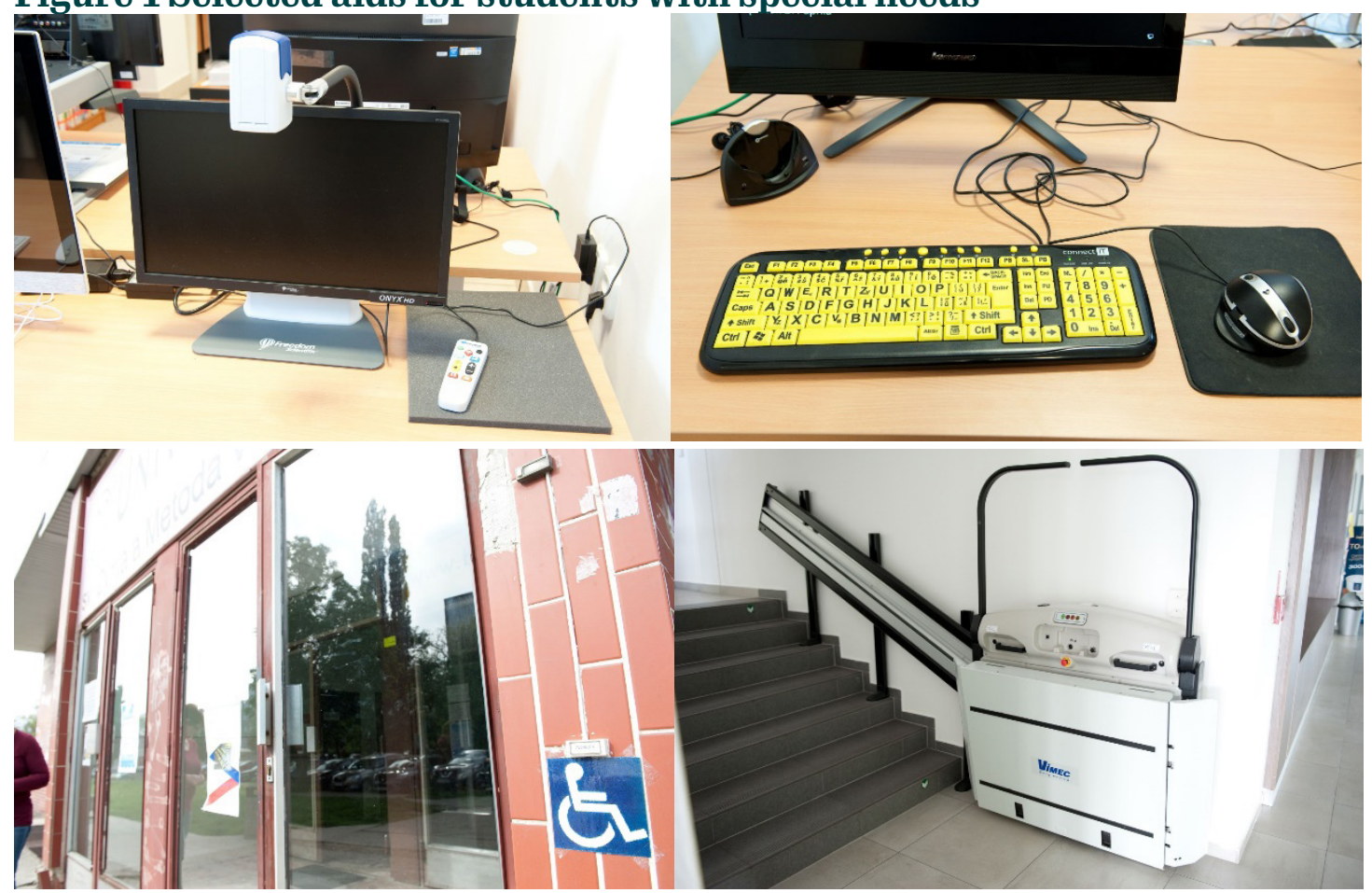

Source: Placement of aids for students with special needs, 2021 [9]

Within the programs of the European Union, such as Erasmus University of St. Cyril and Methodius in Trnava has not yet accepted or sent students with special needs for a study stay at a foreign university.

Students with special needs and with disabilities use Act 448/2008 Coll. on social services [12] and Act 447/2008 Coll. on cash benefits to compensate for severe disabilities and on the amendment of certain laws [13].

Figure 2 Selected compensatory aids for people with disabilities

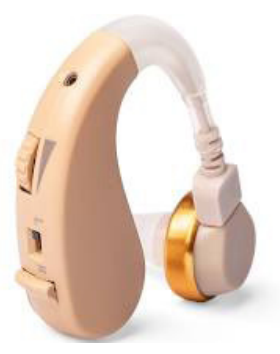

phone for the blind

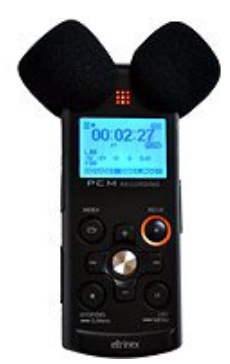

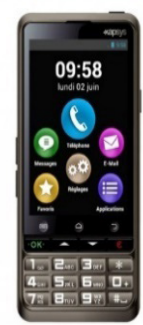

hearing aid dictaphone

Source: Bočáková, O., Hrnčárik, A., Draková, Z. (2021). Social work in healthcare [1]

\subsection{Students with special needs at the Faculty of Social Sciences UCM in Trnava}

As we operate at the Faculty of Social Sciences UCM in Trnava, we approach the possibilities of student intervention with specific needs at the faculty. Overview of the number of students with special needs in the last five years: from 2016/2017 to 2020/2021. 


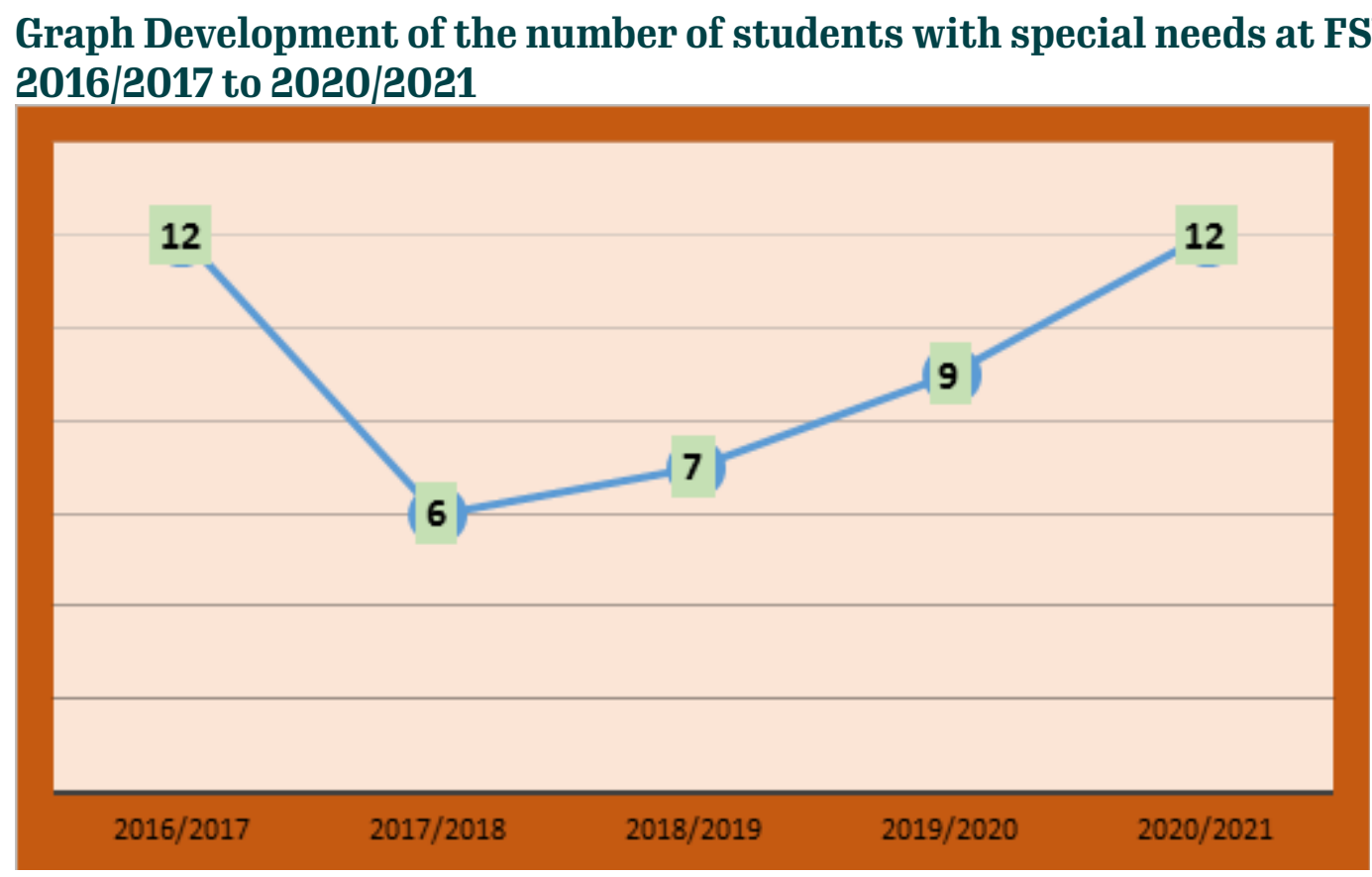

Source: Own processing on the basis of the Evaluation Report of the Support Centre for Students with Special Needs

The education of students with special needs in the environment of the Faculty of Social Sciences UCM in Trnava represents the equal right of every young person to a quality education. Emphasis is placed on the possible removal of barriers at the level of education, when a situation may arise that prevents equal access to education for various reasons (administrative, deteriorating health, social, especially financial indicators, architectural barriers, prejudices, communication barriers, etc.). Our Faculty of Social Sciences UCM in Trnava also has students with special needs in its study programs. Working with them is very good, because based on their history we can create conditions for their study, and so we achieve satisfaction on both sides.

Based on interviews with students with special needs, we considered creating a suitable environment for students with special needs. It is from their initiation that a relaxation room is created for students with special needs, so that while waiting for lectures, relaxation and mutual communication, they have a place to rest. Students with special needs are also allowed professional practice, of course, their disability is taken into account.

Although these students have a certain disadvantage compared to healthy ones, their enthusiasm, involvement in various activities, responsible approach to study are pearls that form the framework of their efforts and determination to prove that they are equal and have the full right to influence their lives and lives. society. Let's keep our fingers crossed and create opportunities for them to realize and be happy.

\section{Method}

We used a qualitative method, an interview method. The interview was semi-standardized. The aim of the interviews was to find out:

- What support services are most used by students with special needs.

- What is the cooperation of students with special needs with the faculty coordinator.

- How do students with special needs at the Faculty of Social Sciences UCM in Trnava evaluate support services?

We recorded the participants' answers with their consent. Subsequently, we analyzed and processed them.

\section{Participants}

We conducted the interview:

- with the Vice-Rector for Education at UCM in Trnava, whose competencies also include students with special needs (P1) 
- with the head of the Support Center for Students with Special Needs (P2)

- with the faculty coordinator of the Faculty of Social Sciences UCM in Trnava (P3)

- with selected students with specific needs of the Faculty of Social Sciences UCM in Trnava (P4-P9)

\section{Results}

The Vice-Rector for Education of UCM in Trnava clarified how the Support Centre for Students with Special Needs works, informed us what its goal and main tasks are. The head of the Support Centre for Students with Special Needs maintains a database of students enrolled as students with special needs. Keeps records of purchased aids for students. The faculty coordinator of FSV UCM already communicates specifically with individual students and finds out what they need for their studies. It also informs individual teachers who participate in lectures and seminars of students with special needs. It informs them about their support services in order to improve teaching. Last but not least, we also addressed selected students who willingly completed the interview with us.

The following tables provide an overview of our participants' answers.

Tab. 1 The most used support services for students with special needs

\begin{tabular}{|c|c|c|c|c|}
\hline & P1 & P2 & P3 & P4-P9 \\
\hline computer technology & 1 & 1 & - & 4 \\
\hline barrier-free enter & - & - & 1 & 1 \\
\hline personal assistant & - & - & - & 1 \\
\hline
\end{tabular}

Source: own processing

From the statements of the participants, we can state that the greatest interest on the part of students with special needs is in computer technology, it is an opportunity to use specific educational resources.

Tab. 2 Cooperation of students with special needs with the faculty coordinator

\begin{tabular}{|c|c|c|c|c|}
\hline & P1 & P2 & P3 & P4-P9 \\
\hline good & - & 1 & - & 4 \\
\hline rather good & 1 & & 1 & 2 \\
\hline
\end{tabular}

Source: own processing

It is gratifying that the participants see the cooperation with the faculty coordinator as good or rather good. The faculty coordinator is helpful in solving the student's problems and ensuring conditions during the study for the student.

Tab. 3 Evaluation of support services by students with special needs at FSV UCM in Trnava

\begin{tabular}{|c|c|c|c|c|}
\hline & P1 & P2 & P3 & P4-P9 \\
\hline good & 1 & 1 & - & 3 \\
\hline rather good & - & - & 1 & 3 \\
\hline
\end{tabular}

Source: own processing

University of St. Cyril and Methodius in Trnava provides support services for students through faculty coordinators. Students rate support services as good or rather good.

\section{Discussion}

It is the duty of every democratic state to provide people with disabilities with living conditions that are comparable to those of healthy people. People with disabilities have the same rights as others. [6].

University education and any other type of formal education provides knowledge that, after its completion, is used in a specific specialized sector. Young people are affected by a lack of education, as their chances of employment are slightly lower. The possibility of studying for people with special needs shapes their belief in the perspective of their own lives. [8] 
From the testimonies of our respondents, we learned that one of the most frequently used support services for students with special needs is the use of computer technology for students with disabilities. Providing barrier-free access to the university building is also an important support service for students with special needs. The Faculty of Social Sciences UCM in Trnava already has a stair climber available for students. Personal assistance is also one form of support for students with disabilities. Personal assistance is an important tool for strengthening the social competencies and independence of a person with a disability. [5]

Regarding the cooperation with the faculty coordinator for students with special needs, we can state that the cooperation is at a very good level, which also follows from the answers of our respondents.

The overall evaluation of support services at the Faculty of Social Sciences UCM in Trnava is evaluated by the participants well or rather well. We can state that there is a support system for students with special needs.

\section{Conclusion and implications}

In order to ensure a systematic approach to the study of students with special needs at universities, the Ministry of Education, Science, Research and Sport of the Slovak Republic has established a Council of Ministers to support the study of students with special needs as an advisory body to the Higher Education Section. Legislation obliges universities to create the same opportunities for students with disabilities to study as other students.

In general, universities maintain a database of their students with disabilities. The interviews showed a diversity of approaches to the provision of support services and also some differences in the level of these services. It is necessary to continue the trend of making available and improving support services in order to create equal opportunities for students with disabilities, specific needs.

This paper is part of the project 026UCM-4/2020 "Youth policy as part of civil society."

\section{References}

[1] Bočáková, O., Hrnčárik, A., Draková, Z. (2021). Sociálna práca v zdravotníctve. Trnava: FSV UCM v Trnave.

[2] Dohovor OSN o právach osôb so zdravotným postihnutím a Slovenská republika. (2012). [Online]. from https://www.employment.gov.sk/sk/rodina-socialna-pomoc/tazke-zdravotne-postihnutie/ kontaktne-miesto-prava-osob-so-zdravotnym-postihnutim/dohovor-osn-pravach-osob-sozdravotnym-postihnutim-slovenska-republika.html

[3] Hodnotiaca správa - Centrum podpory študentov so špecifickými potrebami. Trnava: UCM v Trnave.

[4] Rada ministra na podporu štúdia študentov so špecifickými potrebami. [Online]. from https://www. minedu.sk/rada-ministra-na-podporu-studia-studentov-so-specifickymi-potrebami/

[5] Repková, K. (1998). Občania so zdravotným postihnutím v procese spoločenskej integrácie - medzinárodné dokumenty a skúsenosti, Bratislava: Epos.

[6] Repková, K., Sedláková, D. (2012). Zdravotné postihnutie - vybrané fakty, čísla a výskumné zistenia $v$ medzinárodnom a národnom kontexte. Bratislava: Kancelária WHO na Slovensku.

[7] Smernica na zabezpečenie všeobecne prístupného akademického prostredia pre študentov so špecifickými potrebami. [Online]. from https://www.ucm.sk/sk/centrum-podpory-studentov-so-specifickymi-potrebami-01/

[8] ŠMIDOVÁ, M. (2013). Students with Special Needs in the University Environment. Studia Aloisiana, 5, 2013, 1, s. 31-43.

[9] Umiestnenie pomôcok pre študentov so špecifickými potrebami. [Online]. from https://www.ucm. sk/sk/centrum-podpory-studentov-so-specifickymi-potrebami-01/

[10] Vyhláška č. 458/2012 Z. z. - Vyhláška Ministerstva školstva, vedy, výskumu a športu Slovenskej republiky o minimálnych nárokoch študenta so špecifickými potrebami. [Online]. from www. zakonypreludi.sk/zz/2012-458 
[11] Zákon č. 131/2002 Z. z. o vysokých školách a o zmene a doplnení niektorých zákonov. [Online]. from https://www.zakonypreludi.sk/zz/2002-131

[12] Zákon 448/2008 Z.z. o sociálnych službách. [Online]. from https://www.zakonypreludi.sk/zz/2008448

[13] Zákon 447/2008 Z.z. o peňažných príspevkoch na kompenzáciu tažkého zdravotného postihnutia a o zmene a doplnení niektorých zákonov. [Online]. from https://www.slov-lex.sk/pravnepredpisy/SK/ZZ/2008/447/ 